\title{
PENDAMPINGAN PENJUALAN ONLINE PADA PEDAGANG PASAR TRADISIONAL LANDUNGSARI KECAMATAN DAU KABUPATEN MALANG
}

\author{
Ida Nuraini $^{1 *}$, Syamsul Hadi ${ }^{2}$ \\ ${ }^{1}$ Program Studi Ekonomi Pembangunan, Universitas Muhammadiyah, Malang, Indonesia \\ *Email: nurainiida@yahoo.com
}

\begin{abstract}
Informasi Artikel Abstrak
Kata kunci :

Penjualan online,

Pedagang,

Pasar Tradisional.

Diterima: 07-12-2020

Disetujui: 19-05-2021

Dipubikasikan: 14-07-

2021

Target pemerintah 10 juta Usaha Mikro Kecil Menengah menggunakan platform online pada akhir tahun 2020 belum tercapai, salah satunya adalah pedagang pasar tradisional agar dapat berjualan secara online. Tujuan kegiatan pengabdian masyarakat ini adalah melatih dan mendampingi pedagang pasar tradisional Landungsari agar dapat berjualan secara online melalui aplikasi Instagram dan Facebook bisnis. Pelatihan dimulai dari teknik membuat akun Instagram bisnis dan Facebook bisnis, teknik memfoto produk, mengupload foto/video, teknik mencari pelanggan, teknik packaging dan cara pengiriman produk. Kegiatan dilaksanakan pada bulan April-September 2020 atau saat mewabahnya virus COVID-19. Akibat COVID-19, mitra pengabdian yaitu pedagang sayur mengalami penurunan pendapatan dari 4-5 juta rupiah menjadi 1-2 juta rupiah per hari. Mitra lainnya yaitu penjual makanan beku juga mengalami penurunan omzet penjualan dari 5-7 juta rupiah turun menjadi 4-5 juta rupiah per hari. Setelah diberi pelatihan penjualan online mitra banyak menerima pesanan lewat WhatsApp yang meminta produk diantar atau dikirim ke alamat konsumen. Penjualan mitra meningkat rata-rata sebesar $10-40 \%$, walaupun penjualan tersebut masih dibawah rata-rata penjualan sebelum adanya COVID-19. Penjualan online terbukti mampu meningkatkan omzet pedagang pasar tradisional, sehingga diharapkan pedagang lain melakukan penjualannya secara online disamping offline.
\end{abstract}

Keywords :

Online Sales, Merchant,

Traditional Market

\section{Abstract}

The Government's target of 10 million Micro, Small and Medium Enterprises using online platforms by the end of 2020 has not been achieved, one of which is traditional market traders to be able to sell online. The purpose of this community service activity is to train and assist Landungsari traditional market traders to be able to sell online through the Instagram and Facebook business applications. The training starts with techniques for creating business Instagram and business Facebook accounts, techniques for photo products, uploading photos/videos, techniques for finding customers, packaging techniques and how to deliver products. The activity was carried out in April-September 2020 or during the outbreak of the COVID-19 virus. As a result of COVID-19, community 
service partners, namely vegetable traders, experienced a decrease in income from 4-5 million rupiah to 1-2 million rupiah per day. After online sales training, many partners receive orders via WhatsApp requesting that the product be delivered or sent to the customer's address. Partner sales increased by an average of $10-40 \%$, even though these sales were still below the average sales before the existence of COVID-19. Online sales are proven to be able to increase traditional market traders' turnover, so it is hoped that other traders will make their sales online as well as offline.

\section{PENDAHULUAN}

Usaha Mikro Kecil Menengah (UMKM) perlu mendapatkan perhatian khusus dari pemerintah karena UMKM ini memiliki kontribusi yang besar terhadap Produk Domestik Bruto (PDB) Indonesia yang mencapai $61,41 \%$ dengan jumlah UMKM hampir mencapai 60 juta unit (BPS, 2019). Namun sayangnya di masa kemajuan teknologi informasi saat ini dari jumlah UMKM tersebut hanya $8 \%$ atau sebanyak 3,79 juta pelaku UMKM yang telah memanfaatkan platform online untuk memasarkan produknya. Jumlah UMKM di Indonesia yang sangat banyak merupakan potensi yang harus terus dikembangkan agar kontribusinya dalam perekonomian lebih meningkat khususnya dalam menyerap lapangan kerja dan pertumbuhan ekonomi. Dengan mengajak UMKM tersebut untuk selalu mengikuti perkembangan teknologi informasi terkini akan terbuka peluang pasar yang lebih luas dan dapat meningkatkan skala usahanya. Jika dikaitkan dengan jumlah pengguna internet yang mengalami pertumbuhan yang sangat pesat dari tahun ke tahun, maka hal ini menambah peluang bagi UMKM untuk meluaskan skala usahanya melalui transaksi online. Berdasar data yang diperoleh dari publikasi Asosiasi Penyelenggara Jasa Internet Indonesia (APJII), saat ini ada 196,7 juta pengguna di Indonesia. Angka pengguna internet tersebut diperoleh dari hasil survei penetrasi dan perilaku pengguna internet di Indonesia 2019-2020 (Q2). (Asosiasi Penyelenggara Jasa Internet Indonesia, 2020). Dibanding dengan jumlah pengguna internet tahun 2017 yaitu sebanyak 84 juta dan tahun 2018 meningkat menjadi 95,2 juta berarti laju peningkatan pengguna internet semakin tinggi. Hal ini merupakan peluang bagi tumbuhnya transaksi perdagangan online. Dari jumlah pengguna internet di Indonesia tersebut jejaring sosial yang banyak digunakan oleh masyarakat adalah Facebook yaitu sebanyak $48 \%$. Pengguna internet yang makin tumbuh pesat saat ini mamacu pergeseran pola pemasaran di seluruh aspek bisnis. Pemasaran dengan menggunakan internet atau yang lebih dikenal dengan emarketing merupakan cara baru pemasaran produk yang sesuai dengan perkembangan situasi dan kondisi saat ini, khususnya di tengah pandemi virus COVID-19 yang mengharuskan adanya jaga jarak dan banyak menyebabkan orang takut untuk melakukan kegiatan di luar atau di keramaian. Selama COVID-19 ada pergeseran konfigurasi pemanfaatan internet. Pada masa sebelum COVID-19 konfigurasi pemanfaatan internet sebagian besar di kantor, sekolah, kampus dan tempat publik, maka semasa COVID-19 konfigurasi meluas ke perumahan, pusat bisnis dan pemukiman. Seiring dengan itu pertumbuhan pengguna seluler di Indonesia yang mencapai 355,5, juta atau lebih banyak dari jumlah penduduk akan semakin memudahkan segala aktivitas khususnya terkait dengan penjualan 
online, bahkan pada bulan Mei 2020 tercatat terjadinya peningkatan aktivitas ekonomi e-commerce mencapai 40,6\%. (Kominfo, 2020)

Pasar tradisional merupakan salah satu sektor usaha yang rentan terhadap situasi pandemi COVID-19, oleh sebab itu pemerintah berupaya terus mendorong UMKM kususnya pasar tradisional untuk di revitalisasi agar dapat menggunakan platform e-commerce dalam menjalankan transaksi bisnisnya karena bisnis offline saat ini tidak bisa dijalankan secara normal serta sebagai upaya pemerintah dalam mencegah penularan virus COVID-19. Disamping itu sebagai langkah pemerintah dalam mewujudkan "Gerakan UMKM Go Online" yang merupakan salah satu wujud upaya pemerintah dalam pemerataan akses digitalisasi ke seluruh lapisan masyarakat. Untuk itu pemerintah menggandeng banyak pihak dalam program revitalisasi pasar tradisional tersebut diantaranya adalah dengan menggandeng LinkAja untuk memudahkan pembayaran transaksi online dan juga dengan transportasi online. Bahkan beberapa kota di Indonesia telah meluncurkan aplikasi belanja online di pasar tradisional untuk masyarakatnya. Untuk itu perlu adanya kesiapan bagi para pedagang pasar tradisional tersebut berupa pengetahuan dan ketrampilan teknis cara-cara berjualan online. Sekitar 70\% Pengusaha kreatif mengatakan bahwa online channel akan menjadi platform komunikasi utama dalam pemasaran, dikarenakan kemudahan, dan kemampuan untuk perbandingan dengan produkproduk lain dalam waktu yang singkat (Barus, 2016). Sejalan dengan itu, hasil penelitian mengenai keputusan pembelian konsumen secara online menyimpulkan bahwa variabel manfaat bertransaksi merupakan variabel dominan yang mempengaruhi konsumen memutuskan berbelanja secara online. (Mardiani \& Imanuel, 2013)

Berdasar data yang dipublikasi hasil survei Badan Pusat Statistik (BPS) tahun 2018 kepada 16.021 pusat perdagangan di Indonesia, sebanyak 88,52\% merupakan pasar tradisional (14.182) dan sisanya berupa toko modern $(7,06 \%)$ dan pusat perbelanjaan sebanyak $4,42 \%$. Banyaknya jumlah pasar tradisional di Indonesia yang sebagian besar merupakan pedagang pasar tradisional pada umumnya masih banyak yang tertinggal dalam penggunaan internet. Pemanfaatan internet melalui telepon selular genggam sebagian besar di kalangan pedagang pasar tradisional hanya untuk telpon, WhatsApp, SMS, Facebook dan sebagian lainnya yang lebih maju menggunakan instagram dan untuk perdagangan online serta untuk mengunduh permainan. Padahal jika mereka dapat menggunakannya untuk menggali informasi dan untuk berjualan maka akan dapat meningkatkan omzet mereka khususnya di masa new normal seperti sekarang ini. Namun hingga saat ini belum banyak UMKM yang menggunakan internet untuk keperluan menumbuhkan usahanya. Ada beberpa kendala yang menghambat mereka dalam menggunakan internet seperti kurangnya ketrampilan dan pengetahuan penggunaan internet. Hasil penelitian terhadap UMKM dalam menggunakan internet menunjukkan bahwa pemanfaatan komputer dan internet untuk mendukung pengelolaan atau manajemen UMKM mereka pada umumnya relatif masih rendah. Hasil penelitian ini juga sangat jelas menggambarkan bahwa persoalan tingkat pendidikan pelaku UMKM sangat berkorelasi dengan kemampuan mereka 
memanfaatkan TI sebagai sarana pendukung pengelolaan UMKM. (Saleh \& Hadiyat, 2016). Jika kondisi di Indonesia saat ini dengan konsumen yang sangat didominasi oleh usia muda yang melek internet, dengan kebiasaan belanja secara online, maka UMKM harus berani membuat terobosan untuk memanfaatkan internet dalam pemasaran hasil produksinya. Dalam buku yang berjudul Perilaku Konsumen di Era Digital (Febriani, 2019), disebutkan bahwa saat ini terjadi perubahan pada pola belanja masyarakat yang semakin bergeser ke arah online shopping, sehingga banyak penjual yang melakukan penjualan secara online. Di samping itu terjadi pertumbuhan industri e-commerce yang sangat cepat di Indonesia.

Pasar Desa Landungsari, Kecamatan Dau, Kabupaten Malang merupakan salah satu pasar tradisional yang lokasinya merupakan perbatasan dengan wilayah Kota Malang. Pasar Landungsari merupakan pasar hasil pemekaran dari pasar Dinoyo Kota Malang setelah dilakukan revitalisasi, sehingga sebagian pedagang berpindah tempat ke lokasi baru yaitu ke Pasar Desa Landungsari yang tidak terlalu luas. Di pasar Landungsari ini hampir sebagian besar pedagang berasal dari daerah Landungsari dan sekitarnya. Pasar tradisional Landungsari memiliki kelebihan yang sangat baik dalam menumbuhkan ekonomi kerakyatan diantaranya adalah dalam hubungan sosial para pelakunya. Antara pemasok barang, pedagang dan pembeli memiliki hubungan yang erat yang ditunjukkan oleh adanya paguyuban pedagang dan pemasok. Fungsi paguyuban adalah saling membantu jika dari anggotanya mengalami musibah, saling menjualkan barang antar sesama pedagang ataupun pemasok jika salah satu pedagang sudah habis barang dagangannya sementara yang lain belum habis. Melakukan arisan secara harian yang bisa di atur siapa yang akan memperoleh lebih dulu berdasar keperluan anggota mendesak atau tidak. Semangat kebersamaan sangat kental sekali dan tidak terlihat adanya kompetisi diantara pedagang satu dengan yang lain. Sebagaimana hasil penelitian terhadap pasar tradisional di Monju yang menyimpulkan bahwa pasar tradisional tidak hanya berfungsi melakukan transaksi jual beli yang bernilai ekonomis, namun juga memberikan dampak sosial kepada masyarakatnya. Hubungan sosial yang terbangun di pasar adalah komunikasi interpersonal antara pedagang serta bentuk tawar menawar yang mendekatkan hubungan sosial pedagang dan pembeli yang dapat menumbuhkan nilai kekeluargaan, persaudaraan, kebersamaan, kerjasama, rasa empati, dan gotong royong. Nilai-nilai sosial ini menjadi daya tarik bagi masyarakat untuk melakukan kunjungan ulang ke pasar sehingga memiliki daya tarik wisata yang bernilai sosial. (Syarifuddin et al., 2018).

Pasar Landungsari sebagaimana pasar tradisional lainnya memiliki ciri khas bangunan dengan atap yang luas dan tanpa sekat, sehingga pedagang tidak terkotak-kotak di dalam bangunan tetapi berderet deret tanpa sekat dengan dagangan sebagian berada di atas meja dan sebagian pedagang lain tidak memiliki meja sehingga menaruh dagangannya di atas tanah dengan menggunakan alas plastik ataupun keranjang. Berdasar karakteristik pedagangnya sebagian besar merupakan orang-orang yang berusia di atas 50 tahun, namun ada sebagian yang masih muda dengan usia berkisar 30-40 tahun. 
Pedagang dengan usia antara 30-40 ini merupakan pedagang yang aktif menggunakan telepon selular untuk membantu kegiatan jual belinya seperti melalui telepon, SMS dan WhatsApp baik untuk komunikasi dengan konsumennya maupun dengan pemasoknya. Sebagian besar pedagang pasar memiliki pelanggan atau pembeli tetap karena pedagang memberi kemudahan dalam sistem pembayaranya yaitu dengan tempo sehingga hubungan antara penjual dan pembeli adalah bersifat saling percaya meskipun tidak ada nota penjualan ataupun pembelian. Jam operasi pasar dimulai dari pukul 02.00 malam hingga pukul 12.00 siang, namun sebagian besar pedagang sudah tutup pukul 10.00 pagi. Sebagian besar pedagang Pasar Landungsari 150 lebih pedagang berjualan sayuran, sekitar 50 orang berjualan ikan, ayam dan daging sapi, 20 pedagang berjualan sembako dan 50 orang lebih berjualan lain-lain seperti kue, perabot rumah tangga, bunga dan baju.

Pasar Landungsari meskipun tergolong pasar tradisional yang kecil, namun transaksinya bernilai besar karena berada di lokasi yang strategis yaitu berada di daerah pemukiman yang padat penduduk khususnya para pendatang seperti mahasiswa dan pekerja serta penduduk pendatang yang kemudian menetap. Padatnya pemukiman di daerah Landungsari dan sekitarnya mengakibatkan tingginya permintaan terhadap kebutuhan sehari-hari di pasar Landungsari. Pelanggan pedagang pasar sebagian besar berbelanja dalam jumlah banyak seperti warung makan, restoran, catering dan rumah tangga. Cara transaksi sebagian pedagang sudah dilakukan secara online yaitu melalui WhatsApp. yang biasanya pembeli berkomunikasi dengan penjual untuk melakukan pemesanan barang yang akan dibeli dan pedagang kemudian menyediakannya. Komunikasi antara pedagang dan pemasok sudah biasa dilakukan melalui SMS, telepon ataupun WhatsApp tergantung dari kemampuan masing-masing pedagang. Berdasar pengamatan terhadap pedagang pasar, mereka yang berusia tergolong muda (di bawah 40 tahun) sebagian besar sudah dapat berkomunikasi melalui telepon selular, namun untuk pedagang di atas 50 tahun sebagian besar tidak menggunakan fasilitas telepon selular.

Adanya COVID-19 mengakibatkan banyak pelanggan besar pedagang pasar tersebut seperti hotel, restoran, warung makan, catering, pondok pesantren dan sekolah-sekolah full day yang tidak berbelanja lagi karena aktivitas usahanya tutup. Berdasar wawancara yang telah dilakukan pelaksana kepada mitra yaitu pedagang sayuran bernama Tedi Setiono yang sudah 5 tahun berjualan mengatakan bahwa omzet penjualan saat ini mengalami penurunan dari Rp 4-5 juta per hari saat COVID-19 ini turun menjadi Rp 1-2 juta. Produk yang dijual bapak Tedi adalah kentang, bawang putih, bawang merah, cabe, wortel, kobis, kol, sawi, labu dan jenis sayuran lainnya. Mitra pengabdian lainnya yaitu Ibu Isnaini penjual makanan beku omzet per hari sebelum COVID-19 berkisar Rp 5-7 juta, selama COVID-19 menurun menjadi Rp 4-5 juta per hari. Produk yang dijual ibu Isnaini adalah berbagai makanan beku seperti sosis, nugget, bakso, kebab dsb. Rata-rata pedagang pasar menurun omzet penjualannya selama COVID-19 ini sebesar 50-60\%. Seperti hasil penelitian yang dilakukan terhadap pedagang pasar di Klaten dan Wonogiri yang menunjukkan bahwa dengan adanya pandemi virus COVID-19 ini perekonomian mengalami penurunan terutama pada pedagang pasar yang mengalami 
penurunan omzet dan penghasilan sebesar 50\% (Azimah et al., 2020). Demikian pula yang dialami oleh pedagang sayur dan buah di pasar tradisional Pajak Pagi Pasar V Padang Bulan, mereka mengalami penurunan jumlah penjualan rata-rata sebesar 50\% dibanding sebelum adanya COVID-19. (Sinaga \& Purba, 2020). Menurunnya pendapatan selama COVID-19 tidak hanya dialami oleh pedagang saja, namun seluruh masyarakat yang berpenghasilan tidak tetap menerima dampak yang sama. Seperti hasil penelitian terhadap aktivitas ekonomi masyarakat di Tolitoli Utara yang menunjukkan hasil bahwa Pandemi COVID-19 berdampak terhadap aktivitas ekonomi masyarakat Desa Salumpaga, setelah diberlakuknnya aturan pemerintah dalam pencegahan penyebaran COVID19, yaitu: pendapatan masyarakat (pedagang, nelayan dan petani) semakin menurun, banyak fasilitas (umum) ekonomi yang ditutup, ekonomi masyarakat dan daerah menurun, harga jual hasil nelayan dan petani sayur, buah dan hasil bumi turun, sementara harga kebutuhan pokok semakin melonjak. (Ferdi, 2020). Ada beberapa usaha yang selama COVID-19 mampu bertahan dan justru dapat meningkatkan pendapatannya. Hasil penelitian membuktikan bahwa industri yang mampu bertahan di masa pandemic COVID-19 adalah: 1) UMKM yang mampu mengadaptasikan bisnisnya dengan produk-produk inovasi; 2) Industri ritel yang mampu bertahan, hal ini dikarenakan sebagian memanfaatkan penjualan melalui marketing digital; 3) Industri lain yang mampu bertahan dimasa pandemi COVID-19 adalah industri yang terkait dengan pemenuhan kebutuhan dasar, antara lain listik, air bersih, pertanian, peternakan, perkebunan, perikanan, otomotif dan perbankan. Industri yang mengalami perkembangan selama masa pandemic COVID-19 adalah pangan, farmasi, teknologi Informasi dan komunikasi (Rosita, 2020). Dengan demikian upaya inovasi dan marketing digital sangat penting dilakukan oleh pelaku bisnis agar dalam situasi COVID-19 yang tidak diketahui kapan akan berakhir ini pelaku usaha dapat bertahan dan justru meningkatkan pendapatannya.

Mitra pengabdian saat ini sudah memiliki telepon seluler dengan fasilitas android dan dilengkapi dengan paket data internet. Namun pemanfaatan internet sebagian besar digunakan sebagai sarana untuk whatshap dan Facebook serta untuk mengunduh lagu-lagu. Menurut mitra smartphone digunakan untuk membantu kelancaran usaha dengan cara menelepon, sms dan whatshap kepada pemasok maupun kepada pelangga. Mitra belum memanfaatkan smartphonenya untuk berjualan melalui Facebook dan Instagram, apalagi melalui marketplace. Mitra menyadari bahwa pembeli mereka hanya sebatas yang sudah mereka kenal saja padahal mereka sebetulnya ingin pembelinya bertambah banyak, namun tidak mengetahui bagaimana cara meningkatkan jumlah pembeli apalagi pada saat COVID-19 sekarang ini.

Berdasar masalah yang dikemukakan pedagang pasar yaitu turunnya penjualan akibat pandemic COVID-19 dan belum dimilikinya ketrampilan berjualan secara online maka diperlukan upaya untuk membantu mitra agar dapat meningkatkan penjualannya selama COVID-19 ini. Oleh sebab itu tujuan kegiatan ini adalah memberi pelatihan teknis berjualan secara online melalui media WhatsApp bisnis, Instagram bisnis dan Facebook bisnis. Pemanfaatan media sosial ini tidak terlalu sulit bagi para 
pedagang, banyak kegiatan pengabdian masyarakat telah berhasil melatih usaha kecil memanfaatkan media soSial dalam memasarkan produknya sehingga pendapatannya meningkat, salah satunya adalah Pelatihan Dan Pendampingan Pemasaran Produk Hasil Homemade Dengan Media Sosial Di Desa Deketagung Kecamatan Sugio Kabupaten Lamongan yang dan berhasil meningkatkan pengetahuan dan kemampuan peserta dalam memanfaatkan media sosial untuk dijadikan sebagai alat pemasaran, dimana ini ditunjukkan dengan adanya perubahan angka rerata pretest dan post tes, seperti nilai dari skor 72 ke skor 100. Pemahaman terakhir dari setiap peserta terhadap media sosial Instagram diperoleh sebesar $75 \%$ lebih besar dari pada pemahaman terakhir dari peserta terhadap website toko online sebesar 65\%. (Handayani, Ghofur, \& Fadhilah, 2020). Pemanfaatan media sosial seperti Instagram, Youtube, dan Facebook juga berhasil meningkatkan pendapatan UMKM pengrajin limbah. Strategi pemasaran online secara langsung mampu meningkatkan dan mengembangkan nilai jual pengrajin, sehingga distribusi produk dalam pasar domestik dapat terselamatkan di masa pandemi COVID-19. (Bakhri \& Futiah, 2020).

\section{METODE}

Dalam rangka mewujudkan mitra agar dapat berjualan secara online maka pendekatan yang digunakan adalah pendekatan edukasi dengan praktek langsung. Tahapan kegiatan Pelaksanaan kegiatan pelatihan dan pendampingan penjualan secara online kepada mitra yaitu melalui tahapan sebagai berikut:

1. Tahap persiapan, pada tahap ini pelaksana dan mitra berkoordinasi untuk menentukan waktu, tempat kegiatan, bahan, alat dan jenis pekerjaan yang harus disediakan dan dijalankan baik oleh pelaksana maupun mitra. Kegiatan disepakati dilakukan pada bulan April-September 2020 pada waktu penjual sedang berjualan di pasar dan mitra menyediakan handphone android sedangkan untuk pembelian paket data dibantu oleh pelaksana selama masa pelaksanaan kegiatan berlangsung.

2. Tahap sosialisasi program, yaitu melakukan sosialisasi kepada mitra tentang tujuan, metode dan manfaat kegiatan yang akan dilakukan agar mitra memiliki semangat dan motivasi untuk memajukan usahanya. Kegiatan ini dilaksanakan pada bulan April 2020.

3. Tahap pelaksanaan, diawali dengan: a) memberi penjelasan kepada mitra mengenai manfaat mitra memiliki media sosial sebagai sarana untuk memasarkan barang; b) Tahap selanjutnya adalah mendampingi mitra praktek cara membuat akun Instagram bisnis, akun Facebook bisnis dan whatsap bisnis; c) pelatihan memfoto produk; d) pelatihan mengupload foto produk ke akun Instagram, WhatsApp bisnis dan Facebook; e) mitra dilatih teknis mencari konsumen secara online maupun offline; f) dilatih cara pengemasan produk yang akan dikirim. Pelaksanaan dimulai pada bulan Mei-September 2020 yaitu saat pandemi COVID-19 dan dilaksanakan bersamaan dengan pedagang saat berjualan di pasar. Pada kegiatan ini mitra diharapkan dapat berpartisipasi aktif 
dalam praktik membuat akun-akun di media sosial, berpartisipasi dalam memfoto produk dan mengupload foto produk tersebut ke akun-akun di media sosial. Berpartisi aktif dalam pengemasan produk dan pengirimannya.

4. Tahap evaluasi, pada tahap ini mitra didampingi oleh pelaksana melakukan evaluasi terhadap kendala-kendala yang dialami selama kegiatan berlangsung dan juga dilatih untuk mengidentifikasi beberapa hal yang dapat menunjang keberhasilan penjualan online. Tahap evaluasi dilaksanakan bersamaan dengan proses pelaksanaan berlangsung.

\section{HASIL DAN PEMBAHASAN}

Keinginan mitra untuk dapat berjualan secara online khususnya di saat pandemi virus COVID-19 memang sangat tepat karena saat pandemi COVID-19 hampir semua penjual di pasar tradisional mengalami penurunan jumlah pembeli sehingga omset penjualan menurun drastis. Turunnya omzet penjualan para pedagang di saat pandemi COVID-19 selain disebabkan oleh pembatasan jam buka operasional pasar juga disebabkan oleh banyaknya pelanggan yang menutup usahanya seperti warung makan, hotel, restaurant dan café sebagai akibat turunnya bahkan tidak adanya konsumen. Dilaksanakannya aktivitas sekolah dan kuliah secara daring maka penduduk kota Malang yang sebagian besar pendatang yaitu mahasiswa menjadi berkurang dan hal ini berdampak pada berkurangnya permintaan kebutuhan sehari-hari khususnya berupa barang-barang yang di jual oleh pedagang pasar. Belum lagi banyak ibu-ibu rumah tangga yang merasa takut ke pasar karena virus corona. Akibat kondisi tersebut pedagang termotivasi untuk bisa berjualan secara online disamping dengan cara offline seperti yang biasa dilakukan setiap hari. Motivasi yang tinggi dari pedagang untuk dapat berjualan secara online merupakan faktor yang dapat mempercepat keberhasilan pedagang itu sendiri.

Mitra yaitu Bapak Tedi dan Ibu Isnaini semula belum memiliki Instagram dan Facebook maka setelah dilakukan pelatihan mereka mampu membuat akun Instagram dan Facebook bisnis sendiri. Di bawah ini adalah akun Instagram mitra yaitu ibu Isnaini penjual makanan beku dan Bapak Tedi penjual sayuran. 


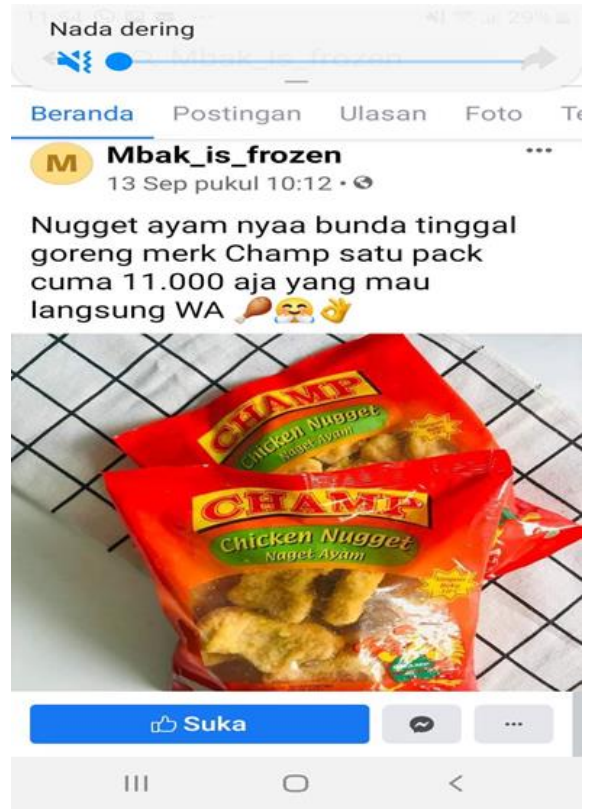

Gambar 1. Instagram Mitra (Ibu Isnaini frozen food)

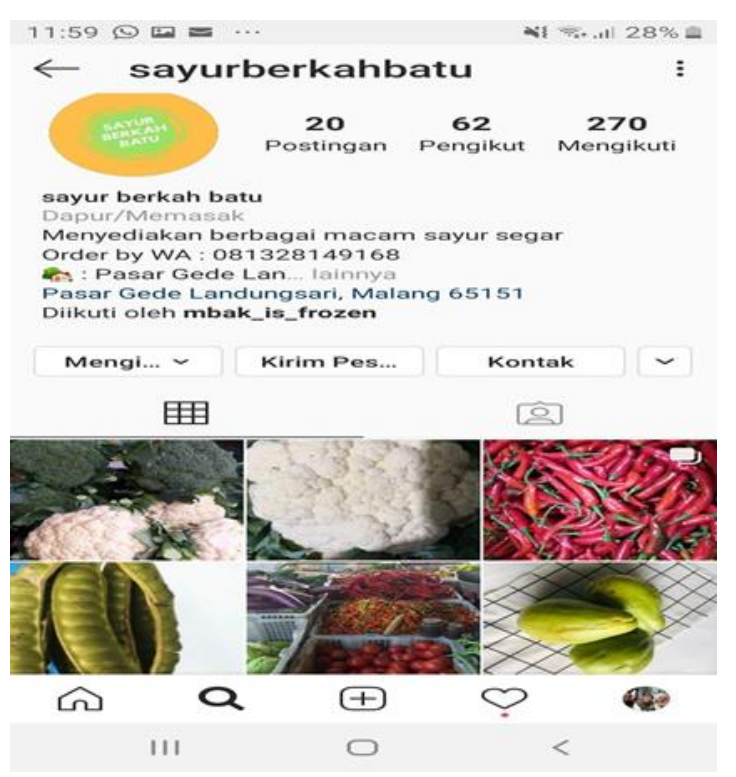

Gambar 2. Instagram Mitra (Bapak Tedi Sayur)

Pelatihan memfoto produk dan mengupload foto produk ke akun instagram dan Facebook sudah dapat dilakukan sendiri oleh Mitra. Mendeskripsikan produk dan memberi keterangan lain sudah bisa dilakukan sendiri oleh Mitra. Dengan dibuatnya akun Instagram dan Facebook tersebut para pedagang dapat melakukan promosi atau menawarkan produknya ke khalayak luas dengan waktu yang tak terbatas. Dalam instagram dan Facebook tersebut pedagang menuliskan nomor handphone untuk pemesanan secara online, sehingga konsumen dengan mudah menghubungi pedagang untuk pesan antar baik sayur maupun froozen food.

Pelatihan lain yang diberikan adalah cara mengemas produk yang telah dibeli oleh konsumen. Dalam hal ini Mitra diberi ketrampilan mulai dari pemilihan barang yang tidak boleh sembarangan karena dapat berdampak pada kepuasan pembeli serta munculnya coment tidak baik dari pembeli 
yang akan berdampak pada minat calon pembeli lain. Ketrampilan membungkus agar produk masih tetap segar, utuh dan dalam kondisi baik sampai ke tangan konsumen dan agar tetap bersih dan tidak rusak, seperti menyesuaikan jenis barang yang dibungkus dengan bahan pembungkusnya serta tetap memperhatikan kebersihan.

Untuk menambah jumlah pembeli, pelaksana melatih mitra supaya aktif mencari alamat calon pelanggan tiap harinya secara online yaitu dengan mencari nomor-nomor telepun serta alamat potensial seperti restaurant, hotel, warung makan, sekolah-sekolah full day dan sebagainya kemudian mitra dilatih untuk memfollow serta mengirim WhatsApp menginformasikan produk-produk mitra. Dengan dimilikinya Instagram ini mitra mulai mendapatkan pesanan secara online dari konsumen di area dekat pasar dan dari wilayah Kota Malang seperti warung makan, rumah tangga, pondok pesantren dan sekolah full day. Dengan adanya penjualan secara online, mitra mendapatkan tambahan pelanggan baru sehingga penjualannya meningkat rata-rata sebesar $10 \%$ walaupun tidak bisa kembali seperti pada waktu sebelum adanya virus COVID-19.

Selain dengan cara online, Mitra dilatih juga mempromosikan dagangannya secara offline seperti menggunakan media banner yang di dalamnya berisi informasi melayani pesan antar dan nomor WhatsApp yang bisa dihubungi untuk pemesanan, sehingga walaupun pasar sudah tutup pembeli dapat melakukan pemesanan ke penjual dengan cara WhatsApp. Mitra juga dilatih dalam pengadaan brosur dan banner mulai menunjukkan tempat pemesanan, cara pemesanannya dan membuat desain serta konten atau isi pesan dalam brosur dan banner tersebut. Di bawah ini merupakan bentuk benner yang di berikan pelaksana kepada mitra yang akan dipasang di kios masing-masing sebagai sarana promosi dan informasi mengenai barang yang dijual, fasilitas yang disediakan serta nomor contact pedagang. Adanya banner diharapkan dapat meningkatkan omzet penjualan karena bagi konsumen yang tidak sempat ke pasar tetap masih dapat berbelanja dengan cara pemesanan online dan barang bisa di antar ke rumah.

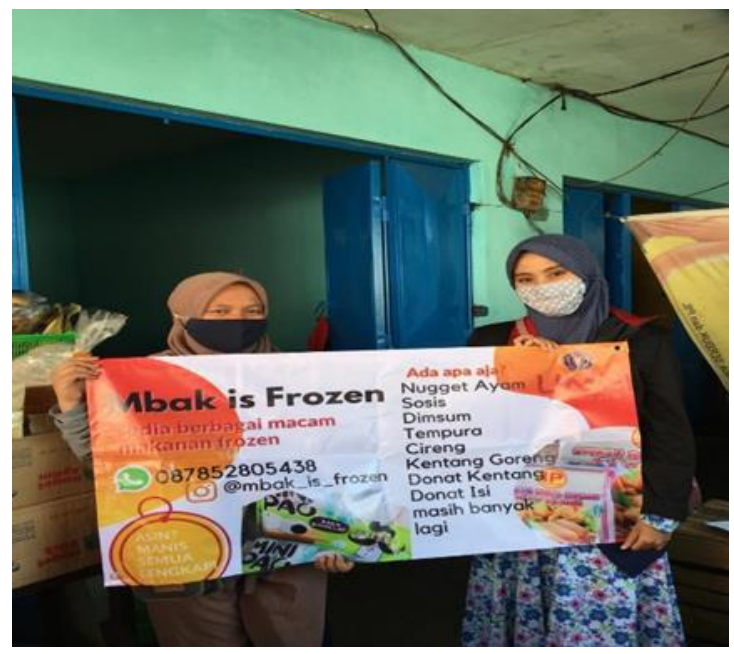

Gambar 3. Banner penjual frozen food 


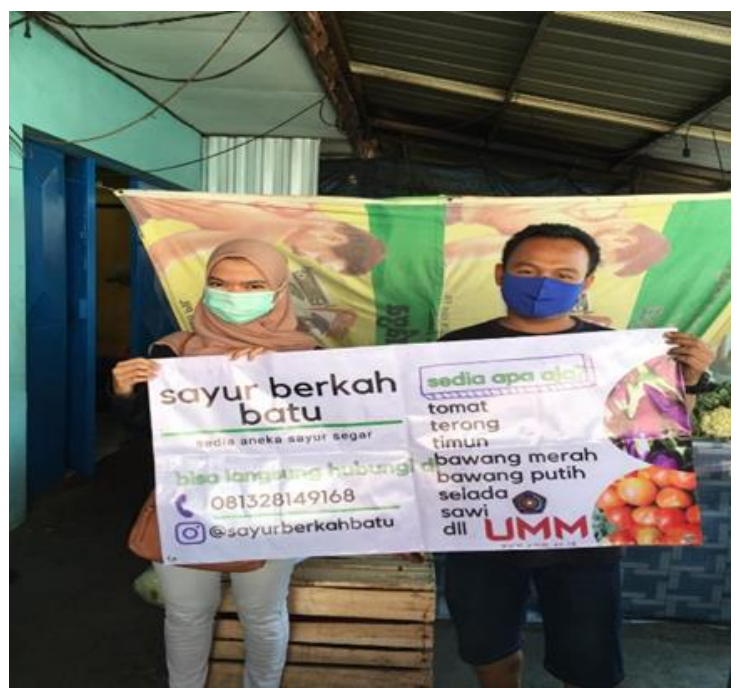

Gambar 4. Banner penjual sayuran

Dengan adanya banner ini pedagang mendapatkan banyak pesanan barang dari konsumen agar barang bisa diantar dengan menambah ongkos kirim dan bahkan di luar dugaan, konsumen tidak hanya meminta barang yang di jual oleh mitra ini saja yaitu sayuran dan makan beku tetapi banyak barang yang dipesan oleh konsumen tersebut yang berasal dari pedangan lain sehingga mitra harus membelikannya kepada pedagang lainnya. Namun hal ini justru dapat menambah keuntungan pedagang karena bertambahnya jumlah item barang yang dibeli konsumen.

Beberapa tanggapan konsumen terhadap pedagang dalam melakukan pembelian secara online dapat dilihat seperti pada contoh chat WhatsApp seperti berikut:

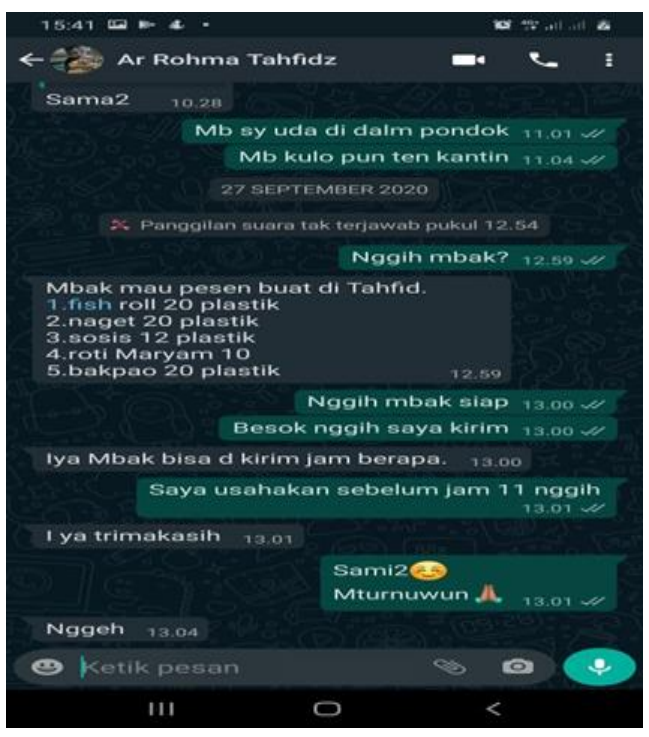

Gambar 5. WhatsApp pemesanan konsumen (setelah dilakukan pelatihan)

Pemesanan konsumen kepada pedagang sebagian besar langsung melalui WhatsApp yang berisi berbagai jenis barang yang kadang barang tersebut bukan berasal dari barang yang dijual oleh mitra dan diminta diantar. Instagram dan Facebook sebagian besar hanya digunakan untuk media 
bertanya, media konsumen untuk melihat informasi harga-harga dan pemesanan barang biasanya tetap dilakukan melalui WhatsApp. Peningkatan omzet penjualan bapak Tedi setelah melayani penjualan secara online berkisar 10-40\%. Jika sebelumnya penjualan per hari berkisar 1-2 juta rupiah, saat ini menjadi 1,5 - 2,8 juta rupiah. Sementara ibu Isnaini dari omzet 4-5 juta rupiah saat ini meningkat menjadi 4,5-6,5 juta rupiah. Disamping adanya peningkatan omzet penjualan setelah melakukan penjualan secara online, pedagang juga telah berhasil menambah jumlah pelanggannya dari berbagai desa di sekitar desa Landungsari yang meliputi kelurahan di wilayah kota Malang dan desa-desa di Kabupaten Malang yang dekat dengan desa Landungsari.

Hingga akhir pelaksanaan kegiatan, pedagang pasar sudah dapat menggunakan handphone secara produktif. Jika biasanya handphone hanya digunakan untuk sekedar melihat-lihat informasi yang tidak ada kaitannya dengan usahanya, maka saat ini pedagang sudah dapat menggunakan handphone nya untuk mencari-cari informasi terkait dengan usahanya. Waktu luang di pasar saat sepi pembeli pedagang juga menggunakan handphone nya untuk melihat informasi ada atau tidak adanya pesanan dari konsumen, dan digunakan untuk terus meng update jenis dagangannya yang baru beserta harganya. Setiap hari pedagang mengirim WhatsApp kepada konsumennya, memberi informasi harga produk atau menanyakan pesanan untuk besuk harinya. Dengan ketrampilan berjualan secara online pedagang sudah pandai memanfaatkan waktu sebaik mungkin dan ini berarti jiwa kewirausahaannya mulai tumbuh. Selama ini pedagang hanya pasif yaitu menggantungkan pembeli yang membeli secara offline atau yang datang ke pasar saja dan tidak pernah ada upaya kreatif untuk berjualan secara aktif. Situasi mewabahnya virus COVID-19 akhirnya memaksa pedagang pasar berlatih berjualan secara online dan berjualan dengan cara pesan antar. Adapun pedagang-pedagang pasar lainnya yang memiliki karakteristik usia diatas 50 tahun sebagian besar sudah tidak mau berjualan secara online dengan alasan tidak mampu menguasai teknologi informasi serta kesulitan lain seperti belum dikuasainya teknik pembayaran non tunai seperti transfer informasi digital atau cashless maupun pembayaran transfer yang melibatkan perbankan.

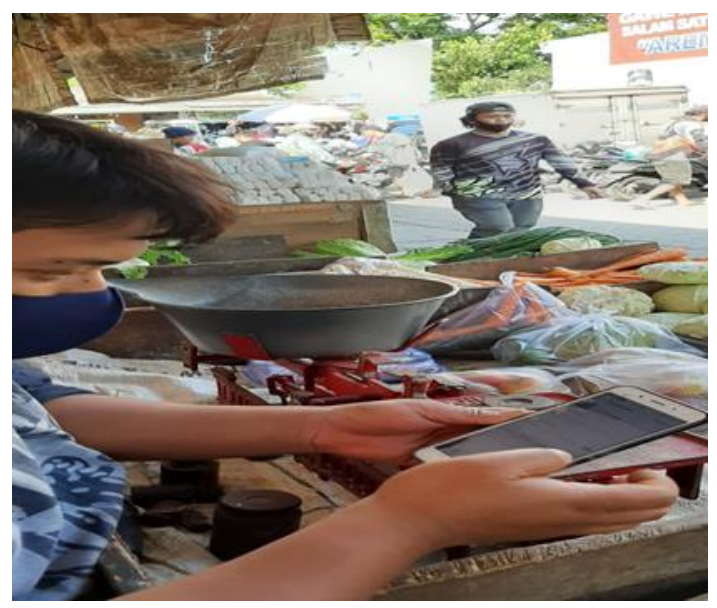

Gambar 5. Pedagang memanfaatkan waktu secara produktif (sedang online saat sepi Pembeli) 
Dengan dilatih untuk aktif memberi informasi dan melakukan promosi kepada konsumen diharapkan mampu meningkatkan omzet penjualan pedagang. Hal yang belum mampu dilakukan pedagang pasar adalah bergabung ke market place. Semua mitra beralasan tidak memiliki waktu yang cukup untuk bergabung dengan market place karena jika bergabung dengan market place maka pesanan yang ada tidak bisa ditunda pengirimannya sementara waktu pedagang efektif kerja mulai jam 2 malam hingga jam 11 siang sudah melelahkan sementara sore hari jam 3 sore sudah harus mengambil barang dagangan untuk di jual esok hari.

\section{KESIMPULAN}

- Kegiatan pengabdian masyarakat yang telah dilaksanakan di Pasar tradisional Landungsari dengan mitra pedagang pasar menunjukkan hasil bahwa pedagang saat ini telah mampu berjualan secara online dan dapat meningkatkan omzet penjualannya. Dalam perkembangannya selain konsumen membeli barang yang di jual oleh mitra, konsumen juga meminta barang lain yang ada di pasar yang di jual oleh pedagang lainnya. Dalam hal ini mitra tetap melayani karena mendapat keuntungan tambahan. Penjualan online yang dilakukan pedagang diawali dari momen yang pas yaitu bertepatan dengan pandemic virus COVID-19 sehingga konsumen lebih banyak yang berbelanja melalui online.

- Pedagang yang semula belum memiliki jiwa kewirausahaan saat ini telah menunjukkan perubahan perilaku seorang yang berjiwa wirausaha dimana mereka telah pandai mengisi waktu luang saat sepi pembeli dengan mengirim informasi terbaru harga-harga barang dagangannya, melalukan pencatatan administrasi usaha dan aktif mencari-cari supplier secara online maupun offline untuk pengadaan barang hari berikutnya.

- Belum bergabungnya pedagang pasar di market place karena kendala teknis seperti keterbatasan waktu, tenaga dan pengetahuan transaksi keuangan non tunai/cashless. Hal ini sedikit demi sedikit akan diusahakan pelaksana untuk terus diberi pelatihan teknis agar ke depan pedagang dapat menguasai penjualan online melalui marketplace ataupun aplikasi-aplikasi lain yang disediakan oleh pemerintah maupun swasta.

- Diharapkan pemerintah daerah Kabupaten Malang dapat memberi fasilitas seperti WiFi di pasar agar menunjang pedagang dalam berjualan secara online. Pedagang lain yang belum melakukan penjualan secara online diharapkan mulai saat ini mau berlatih dan bisa berjualan secara online.

\section{UCAPAN TERIMAKASIH}

Dengan terselesaikannya kegiatan pengabdian masyarakat yaitu Pendampingan Penjualan Online Pada Pedagang Pasar Tradisional Landungsari ini maka Penulis mengucapkan terima kasih kepada Bapak Rektor beserta Direktur DPPM Universitas Muhammadiyah Malang yang telah memberi dukungan finansial sehingga kegiatan pengabdian ini dapat mencapai hasil seperti yang diharapkan sebelumnya yaitu dalam rangka membantu masyarakat mendapatkan kesempatan 
pengembangan usahanya menjadi lebih maju. Semua pihak yang terlibat dalam kegiatan pengabdian ini diantaranya adalah tim mahasiswa Pengabdian Mitra Dosen (PMM), Ketua Paguyuban pedagang Pasar Landungsari yang telah membantu kelancaran pengabdian masyarakat meskipun dalam situasi COVID-19 dan Staf Dosen Program Studi Ekonomi Pembangunan yang telah memberikan saransaran untuk program ini.

\section{DAFTAR PUSTAKA}

Asosiasi Penyelenggara Jasa Internet Indonesia. (2020). Survei Pengguna Internet Indonesia 20192020. Retrieved April 25, 2021, from apjii.or.id

Azimah, R. N., Khasanah, I. N., Pratama, R., Azizah, Z., Febriantoro, W., \& Purnomo, S. R. S. (2020). Analisis Dampak Covid-19 Terhadap Sosial Ekonomi Pedagang Di Pasar Klaten Dan Wonogiri. EMPATI: Jurnal Ilmu Kesejahteraan Sosial, 9(1), 59-68. https://doi.org/10.15408/empati.v9i1.16485

Bakhri, S., \& Futiah, V. (2020). Pendampingan dan Pengembangan Manajemen Pemasaran Produk. Jurnal Loyalitas Sosial, 2(2), 59-70.

Barus, D. H. N. (2016). Peran Internet Dalam Saluran Komunikasi Pemasaran Produk UMKM. Pengaruh Fasilitas Kerja Terhadap Kepuaasan Kerja Karyawan Divisi Sumber Daya Manusia Dan Diklat PT. Dirgantara Indonesia, 12, 77-85.

BPS. (2019). Analisis Hasil SE2016 Lanjutan. Retrieved April 30, 2021, from bps.go.id Febriani, N. S. (2019). Perilaku Konsumen di Era Digital: Beserta Studi Kasus. UB Press.

Ferdi, F. (2020). Dampak Pandemi Covid-19 Terhadap Aktivitas Ekonomi Masyarakat Di Desa Salumpaga, Kecamatan Tolitoli Utara. Geosee, 1, 37-43. Retrieved from http://jurnal.unsil.ac.id/index.php/geosee/article/view/2497

Handayani, S., Ghofur, A., \& Fadhilah, D. N. (2020). Pelatihan Dan Pendampingan Dalam Pengabdian Dan Pendampingan Pemasaran Produk Hasil Homemade Dengan Media Sosial Di Desa Deketagung Kecamatan Sugio Kabupaten Lamongan. 4, 299-304.

Kominfo. (2020). Terjadi Pergeseran Penggunaan Internet selama Masa Pandemi. Retrieved April 20, 2021, from kominfo.go.id

Mardiani, I. E., \& Imanuel, O. J. (2013). Analisis Keputusan Pembelian Konsumen Melalui Media. 4(November).

Rosita, R. (2020). Pengaruh Pandemi Covid-19 Terhadap Umkm Di Indonesia. Jurnal Lentera Bisnis, 9(2), 109. https://doi.org/10.34127/jrlab.v9i2.380

Saleh, B., \& Hadiyat, Y. D. (2016). Use of Information Technology among Performers Micro Small Medium Enterprises in the Border Area (Study in Belu, East Nusa Tenggara) (Penggunaan Teknologi Informasi di Kalangan Pelaku Usaha Mikro Kecil Menengah di Daerah Perbatasan $\begin{array}{llllll}\text { (Studi di Kabupaten } & \text { Bel. Journal Pekommas, } & \text { 1(2), }\end{array}$ https://doi.org/10.30818/jpkm.2016.2010204 
Sinaga, R., \& Purba, M. R. (2020). Pengaruh Pandemi Virus Corona ( COVID-19) Terhadap Pendapatan Pedagang Sayur Dan Buah di Pasar Tradisional “ Pajak Pagi Pasar V” Padang. Regionomic, 2(02), 37-48.

Syarifuddin, D., Tradisional, P., Perspektif, D., Daya, N., Wisata, T., Tentang, S., ... Kunci, K. (2018). Pasar Tradisional Dalam Perspektif Nilai Daya Tarik Wisata. Jurnal Manajemen Resort Dan Leisure, 15(1), 19-32. https://doi.org/10.17509/jurel.v15i1.11266 